\title{
Mechanisms for the Selective Gas-Phase \\ Fragmentation Reactions of Methionine Side Chain Fixed Charge Sulfonium Ion Containing Peptides
}

\author{
Mahasilu Amunugama, Kade D. Roberts, and Gavin E. Reid* \\ Department of Chemistry, Michigan State University, East Lansing, Michigan, USA
}

To enable the development of improved tandem mass spectrometry based methods for selective proteome analysis, the mechanisms, product ion structures, and other factors influencing the gas-phase fragmentation reactions of methionine side-chain derivatized "fixed-charge" phenacylsulfonium ion containing peptide ions have been examined. Dissociation of these peptide ions results in the exclusive characteristic loss of the derivatized side chain, thereby enabling their selective identification. The resultant product ion(s) are then subjected to further dissociation to obtain sequence information for subsequent protein identification. Molecular orbital calculations (at the B3LYP/6-31 $+\mathrm{G}(\mathrm{d}, \mathrm{p})$ level of theory) performed on a simple peptide model, together with experimental evidence obtained by multistage dissociation of a regioselectively deuterated methionine derivatized sulfonium ion containing tryptic peptide, indicate that fragmentation of the fixed charge containing peptide ions occurs via $\mathrm{S}_{\mathrm{N}} 2$ reactions involving the $\mathrm{N}$ - and $\mathrm{C}$-terminal amide bonds adjacent to the methionine side chain, resulting in the formation of stable cyclic five- and six-membered iminohydrofuran and oxazine product ions, respectively. These studies further indicate that the rings formed via these neighboring group reactions are stable to further dissociation by $\mathrm{MS}^{3}$. As a consequence, the formation of b- or y-type sequence ions are "skipped" at the site of cyclization. Despite this, complete sequence information is still obtained because of the presence of both cyclic products. (J Am Soc Mass Spectrom 2006, 17, 1631-1642) (C) 2006 American Society for Mass Spectrometry

$\mathrm{T}$ landem mass spectrometry (MS/MS) methods applied to the gas-phase dissociation of proteolytically derived peptide ions, together with sophisticated bioinformatic tools for interrogation of the resultant product ion spectra against the available protein sequence databases, have become a major enabling technology for protein identification, characterization, and quantitative analysis in the emerging field of proteomics [1-4]. However, the success of these MS/MS based approaches are highly dependant on the ability to derive sufficient structural information from the peptide dissociation reaction to either (1) determine the amino acid sequence of the peptide of interest, via the formation of "sequence" product ions resulting from cleavages along the peptide amide backbone $[5,6],(2)$ selectively identify and characterize post translationally modified (PTMs) peptides, via the formation of characteristic "nonsequence" side-chain cleavage product ions [7], or (3) perform quantitative analysis of differential

Published online August 28, 2006

Address reprint requests to Dr. G. E. Reid, Department of Chemistry, Michigan State University, 234 Chemistry Building, East Lansing, MI 48824, USA.E-mail: reid@chemistry.msu.edu

* Also at the Department of Biochemistry and Molecular Biology, Michigan State University, East Lansing, MI 48824 protein expression levels, via measurement of the relative abundances of characteristic isotopically encoded product ions $[8,9]$. Furthermore, the success of proteomic approaches for protein identification based on the database interrogation of uninterpreted MS/MS product ion spectra are also highly dependant on the ability to accurately predict in silico the types and abundances of the various product ions that will be generated by MS/MS [10, 11]. Although database search algorithms have been extended to account for the changes in peptide mass occurring as a result of common post-translational modifications, such as oxidation, phosphorylation, acetylation, methylation, or glycosylation [12-16], they typically do not account for changes in the MS/MS product ion spectra induced by these modifications. For example, under "nonmobile" proton conditions [17-19], the MS/MS of methionine containing proteins oxidized as a result of post-translational modification or sample handling may result in the dominant characteristic "nonsequence" neutral loss of methane sulfenic acid $\left(\mathrm{CH}_{3} \mathrm{SOH}, 64 \mathrm{Da}\right)$ from the methionine sulfoxide side chain, via a "charge remote" cis 1,2 elimination mechanism [20]. Similarly, phosphorylation of serine and threonine often leads to "nonsequence" fragmentation reactions involving the 


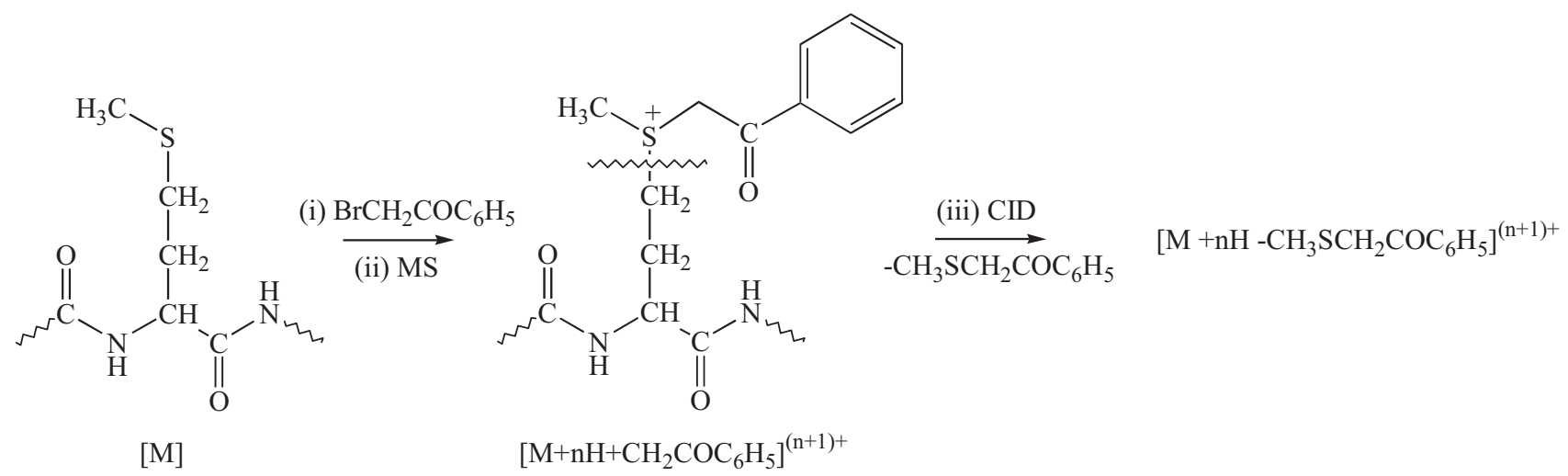

Scheme 1. Fixed charge derivatization and selective gas-phase fragmentation of methionine fixed charge sulfonium ion derivatized peptides.

neutral loss of phosphoric acid $\left(\mathrm{H}_{3} \mathrm{PO}_{4}, 98 \mathrm{Da}\right)$ [7]. In these cases, the "nonsequence" product ion fragmentation pathways may dominate the spectrum, resulting in the suppression of desired "sequence" ions. Therefore, if the dominant "nonsequence" product ion fragmentation pathways are not taken into consideration by the search algorithms, when the required "sequence" ions are in low abundance or absent, low database search scores may result.

Alternatively, it may be desirable to observe these "nonsequence" cleavage product ions so that they could be utilized as diagnostic "targets" for selective proteomic analysis. For example, an approach has recently been demonstrated to quantify protein phosphorylation levels by differential stable isotope labeling and by measurement of the relative abundance of the $\mathrm{H}_{3} \mathrm{PO}_{4}$ neutral loss product ions produced by MS/MS of the singly protonated phosphopeptide ions formed by MALDI [21].

Unfortunately, therefore, the generally limited ability to control or direct the fragmentation reactions of protonated peptide ions during tandem mass spectrometry toward the formation of analytically useful fragmentation pathways places significant limitations on the application of mass spectrometry and associated methodologies for comprehensive proteome analysis $[10,11,22]$. It is expected, however, that a detailed understanding of the mechanisms and other factors controlling the gas-phase dissociation of peptide ions by MS/MS [17-20, 23, 24], coupled with the development of chemical derivatization methods to direct these fragmentation reactions toward desired fragmentation pathways, could lead to significantly improved capabilities for proteome analysis.

To this end, a number of different methods for controlling the fragmentation reactions of peptide ions, involving "fixed charge" derivatization, have been developed [25-30]. Until recently, most of this work has been directed toward derivatization of the $\mathrm{N}$ - and C-termini of the peptide of interest, or the side chains of lysine and arginine residues, and has largely been focused on directing fragmentation toward the forma- tion of a series of "sequence" ions via cleavage along the amide backbone. For example, derivatization to yield an $N$-terminal quaternary phosphonium or ammonium ion results in the formation of a well controlled series of $\mathrm{N}$-terminal b- or a-type product ion series upon MS/MS [26-28], while $N$-terminal sulfonic acid derivatization results in the controlled formation of a series of Cterminal y-type ions [29]. These methods, as well as analogous "nonfixed" charge chemical derivatization approaches [30,31], show great potential to enhance the specificity of database searches for protein identification, by promoting the formation of a contiguous series of product ions, or by promoting the formation of specific product ions, e.g., via enhanced C-terminal aspartic acid cleavage $[30,32]$ or by enhanced $N$ terminal amino acid cleavage [30, 31].

Recently, we described a novel strategy to selectively control the formation of "nonsequence" side-chain fragmentation product ions, by "fixed-charge" sulfonium ion derivatization of methionine containing peptides, for use in selective protein identification, characterization, and quantitative analysis [33]. In contrast to the fixed charge derivatization methods described above, CID-MS/MS of the side-chain sulfonium ion containing peptides results in the formation of a single characteristic product via exclusive loss of the derivatized side chain (Scheme 1). Thus, the fixed charge containing peptide ions may be readily identified from complex mixtures, for example, by selective neutral loss scan mode MS/MS methods. This strategy was also extended to the quantitative analysis of differential protein expression, by measurement of the relative abundances of neutral loss product ions formed by dissociation of "light" and "heavy" isotopically encoded forms of the fixed-charge derivatives. This approach thereby offers the potential for significantly improved sensitivity and selectivity for the identification, characterization, and quantitative analysis of peptides or proteins containing certain structural features, without the requirement for extensive fractionation or otherwise enrichment from a complex mixture before analysis. 
Although several mechanistic possibilities were proposed in the above mentioned work to account for the selective fixed charge side-chain fragmentation reactions observed, involving intramolecular E2 or $\mathrm{S}_{\mathrm{N}} 2$ elimination reactions, extensive studies to determine the operating mechanisms and the potential influence of the resultant product ion structures on subsequent fragmentation reactions were not performed. Determining these mechanisms and product ion structures is of particular importance as characterization of the amino acid sequence of the methionine containing peptides initially identified by the diagnostic loss of the side chain may readily be achieved by further subjecting the initial MS/MS product ions to multistage MS/MS (MS ${ }^{3}$ in a quadrupole ion trap mass spectrometer, or by energy resolved "pseudo" $\mathrm{MS}^{3}$ in a triple quadrupole mass spectrometer [33].

Here, a combination of molecular orbital calculations on a simple peptide model, as well as experimental studies on the multistage dissociation of a regioselectively deuterated methionine derivatized sulfonium ion containing tryptic peptide, have been performed to obtain evidence regarding the mechanism(s) involved in the selective side chain fixed charge fragmentation reactions. These studies indicate that CID-MS/MS of the fixed charge containing peptide ions occurs via $\mathrm{S}_{\mathrm{N}} 2$ reactions involving the $\mathrm{N}$ - and $\mathrm{C}$-terminal amide bonds adjacent to the methionine side chain, resulting in the formation of stable cyclic five- and six-membered iminohydrofuran and oxazine product ions, respectively. These studies further indicate that the rings formed via these neighboring group reactions are stable to further dissociation by $\mathrm{MS}^{3}$. As a consequence, the formation of b- or y-type sequence ions are "skipped" at the site of cyclization. Despite this, complete sequence information is still obtained because of the presence of both cyclic products.

\section{Experimental}

\section{Materials}

Unless stated otherwise, all reagents were analytical reagent (AR) grade and used as supplied without further purification. The synthetic tryptic peptides GAILMGAILK and GAILAGAILK were obtained from Auspep (Melbourne, Australia). Phenacylbromide was purchased from Fluka (St. Louis, MO). Fmoc-chloride, methanol (HPLC grade), and $\mathrm{d}_{4}$-D,L-methionine were purchased from CDN Isotopes (Pointe-Claire, Quebec, Canada). Glacial acetic acid (ACS grade), P-dioxane, magnesium sulfate, and sodium carbonate were purchased from Spectrum Chemicals (Gardena, CA). Acetonitrile (HPLC grade) was purchased from OmniSolv (Gibbstown, NJ). Hydrochloric acid was purchased from Columbus Chemical Industries (Columbus, WI). Diethyl ether was purchased from Jade Scientific (Canton, MI). Ethyl acetate was purchased from Mallinckrodt Chemicals (Phillipsburg, NJ). All solutions were prepared using deionized water purified by a Barnstead Nanopure diamond purification system (Dubuque, IA).

\section{Synthesis of $\left(d_{4}-D, L\right)$-Fmoc-Methionine}

$\mathrm{d}_{4}$-D,L-methionine (100 mg), was dissolved in $10 \%$ $\mathrm{Na}_{2} \mathrm{CO}_{3}(5 \mathrm{~mL})$, to which P-dioxane $(2.5 \mathrm{~mL})$ was added. Fmoc-chloride $(170 \mathrm{mg}$ ) dissolved in P-dioxane $(5 \mathrm{~mL})$ was added dropwise with stirring at $0{ }^{\circ} \mathrm{C}$. The reaction was allowed to proceed for one hour at $0{ }^{\circ} \mathrm{C}$ and then continued for $24 \mathrm{~h}$ at room temperature. The resulting mixture was poured onto $75 \mathrm{ml}$ of ice water and the chloroformate was extracted twice with diethyl ether $(40 \mathrm{~mL})$. The aqueous layer was acidified to $\mathrm{pH} 2$ with concentrated $\mathrm{HCl}$ at $0{ }^{\circ} \mathrm{C}$ then extracted twice with diethyl ether $(40 \mathrm{~mL})$. The organic extracts were combined, dried over $\mathrm{MgSO}_{4}$, then concentrated in vacuo to give Fmoc- $\mathrm{d}_{4}$-D, L-methionine, which was recrystallized from EtOAc-hexane. The GAIL- $\left(\mathrm{d}_{4}\right)$ MGAILK peptide was then synthesized by Syn Pep Company (Dublin, CA).

\section{Side Chain Fixed-Charge Derivatization of Methionine-Containing Peptides}

Side chain fixed-charge sulfonium ion derivatives of synthetic methionine-containing model "tryptic" peptides were prepared by the addition of $10 \mu \mathrm{L}$ of a $1 \mathrm{M}$ solution of phenacylbromide to $100 \mu \mathrm{g}$ of either GAILMGAILK or GAIL- $\left(\mathrm{d}_{4}\right)$-MGAILK dissolved in 100 $\mu \mathrm{L}$ of aqueous $20 \%$ HOAc containing $30 \% \mathrm{CH}_{3} \mathrm{CN}$ as described previously [33]. The reactions were allowed to proceed for $24 \mathrm{~h}$ at room temperature after which the samples were diluted and introduced to the mass spectrometer without further purification. The peptide product is abbreviated as GAILM(R)GAILK where $\mathrm{R}=$ $\mathrm{CH}_{2} \mathrm{COC}_{6} \mathrm{H}_{6}$.

\section{Mass Spectrometry}

Peptides were introduced to a linear quadrupole ion trap mass spectrometer (Thermo model LTQ, San Jose, $\mathrm{CA})$ by electrospray ionization (ESI). Samples, (0.02 $\mathrm{mg} / \mathrm{mL}$ ) dissolved in $50 \% \mathrm{MeOH}, 1 \% \mathrm{AcOH}$ were introduced into the mass spectrometer at $0.5 \mu \mathrm{L} / \mathrm{min}$. The spray voltage was set at $1.8 \mathrm{kV}$. The heated capillary temperature was $200{ }^{\circ} \mathrm{C}$. CID MS/MS and MS $^{3}$ experiments were performed on monoisotopically mass selected ions using standard isolation and excitation procedures.

\section{Computational Methods}

The model peptide $\mathrm{N}$-acetyl methionine (S,S-di-methyl sulfonium)-N-methyl amide $\left(\mathrm{CH}_{3} \mathrm{CONHCH}\left(\mathrm{CH}_{2} \mathrm{CH}_{2} \mathrm{~S}^{+}\right.\right.$ $\left.\left.\left(\mathrm{CH}_{3}\right)_{2}\right) \mathrm{CONHCH}_{3}\right)$ was used for computational calculations. Low-energy transition-state structures related to the possible mechanisms for dissociation of the methionine 


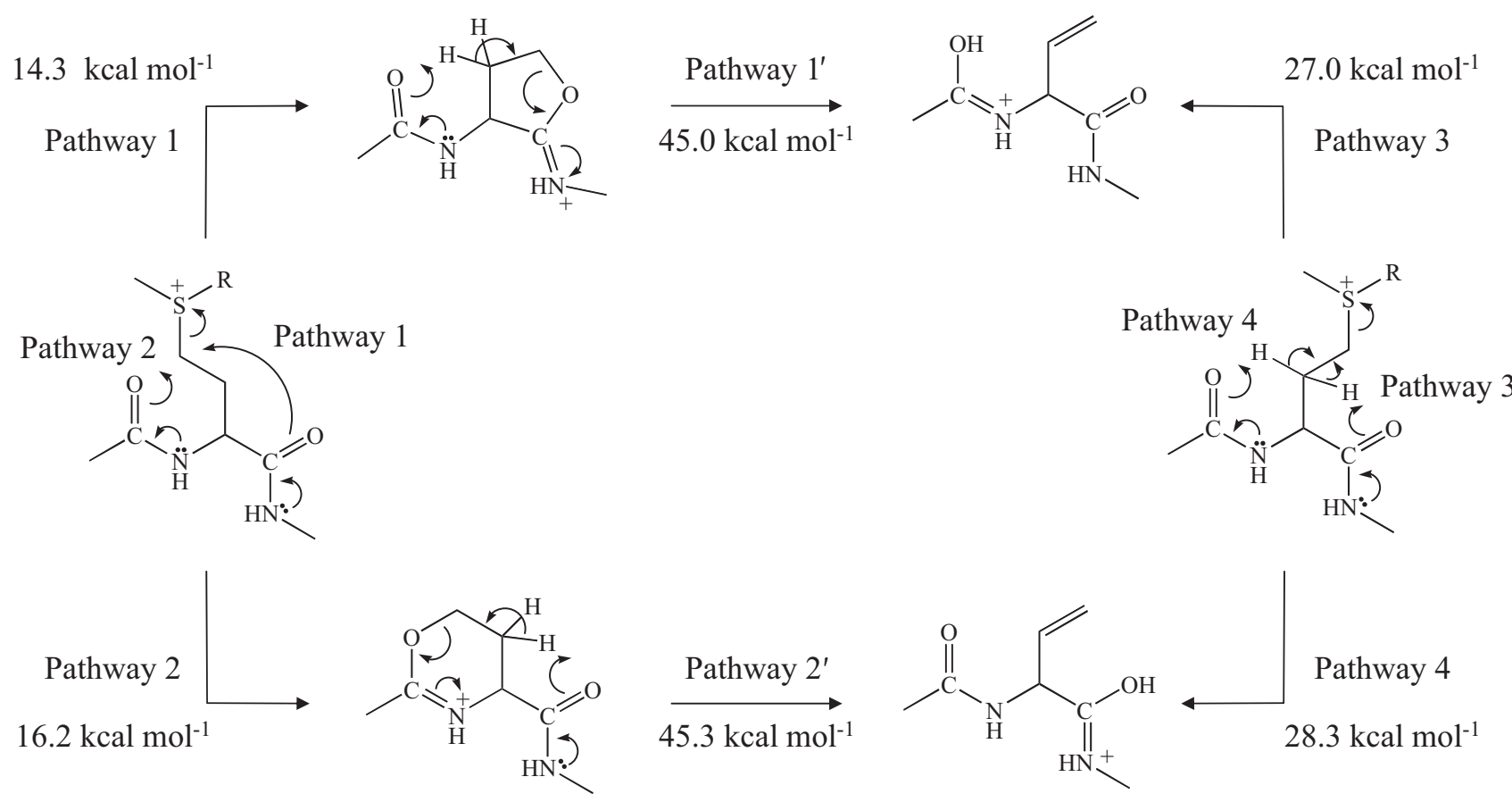

Scheme 2. Potential reaction mechanisms to account for the neutral loss of $\mathrm{CH}_{3} \mathrm{SR}$ from methionine side chain fixed charge containing peptide ions. The predicted activation barriers for each pathway are given relative to Structure (A) in Figure 1.

sulfonium ion side chain were initially found at the PM3 semiempirical level of theory, followed by further optimization at the B3LYP level of theory using the 6-31 + G(d,p) basis set using the Gaussian 98 molecular modeling package [34]. Intrinsic reaction coordinate (IRC) searches were then performed, followed by geometry optimizations to locate the appropriate reactant and product ion structures associated with each transition state. All optimized structures were subjected to harmonic vibrational frequency analysis and visualized using the computer package GaussView 2.1 to determine the nature of the stationary points. Zero point energies were obtained from harmonic frequency calculations without scaling.

\section{Results and Discussion}

\section{Molecular Orbital Calculations to Examine Mechanisms for the Loss of $\mathrm{CH}_{3} \mathrm{SR}$ from Methionine Fixed Charge Sulfonium Ion Containing Peptides}

As shown in Scheme 2, the neutral loss of $\mathrm{CH}_{3} \mathrm{SR}$ from the side chains of methionine fixed charge containing peptide ions could occur via several different mechanistic pathways. Pathways 1 and 2 of Scheme 2 show neighboring group participation reactions involving either nucleophilic attack from the carbonyl group of the $C$-terminal amide bond or the carbonyl group of the $N$-terminal amide bond, respectively. These reaction pathways would result in the formation of protonated five-membered iminohydrofuran or six-membered oxazine product ions, respectively. Alternatively, Path- ways 3 and 4 of Scheme 2 show E2 elimination reactions involving intramolecular proton transfer from the $\beta$ methyl group of the methionine fixed charge containing side chain to the $\mathrm{N}$ - or $\mathrm{C}$-terminal amide carbonyl oxygens to yield protonated acyclic 3-amino-1-butenoic acid (vinyl glycine) product ions. Furthermore, the five-membered iminohydrofuran and the six-membered oxazine product ions formed from Pathways 1 and 2 in Scheme 2 could potentially undergo intramolecular proton transfer ring opening reactions to yield the vinyl glycine product ions (Pathways $1^{\prime}$ and $2^{\prime}$ in Scheme 2, respectively).

To determine which of the mechanistic possibilities described in Scheme $\mathbf{2}$ are energetically feasible, a series of molecular orbital calculations were performed to determine the transition-state barriers associated with each reaction pathway. Potential transition-state structures for each of the possible mechanisms shown in Scheme 2 were initially examined at the PM3 semiempirical level of theory, using a simple peptide model, $\mathrm{N}$-acetyl methionine- $\mathrm{N}$-methyl amide, containing a fixed charge on the thioether side chain, $\mathrm{CH}_{3} \mathrm{CONHCH}\left(\mathrm{CH}_{2} \mathrm{CH}_{2} \mathrm{~S}^{+}\left(\mathrm{CH}_{3}\right)_{2}\right) \mathrm{CONHCH}_{3}$. Low-energy conformers were then reoptimized at the B3LYP/ 6-31 + $\mathrm{G}(\mathrm{d}, \mathrm{p})$ density functional level of theory. Vibrational frequency analysis was then performed to determine the nature of the optimized stationary point structure. Then, intrinsic reaction coordinate searches were performed, followed by geometry optimization at the same level of theory to locate the appropriate precursor and product ion structures associated with 
Table 1. Total energies $\left(\mathrm{E}_{\text {total }}\right)$, zero point vibrational energies (ZPVE) and relative energies $\left(E_{\text {rel }}\right)$ computed for the precursor ions, transition states, intermediate product ions and product ion structures associated with each reaction pathway at the B3LYP $/ 6-31+G(d, p)$ level of theory

\begin{tabular}{|c|c|c|c|}
\hline Structure & $\mathrm{E}_{\text {total }}$ (Hartree) & $\begin{array}{c}\text { ZPVE } \\
\text { (kcal mol-1) }\end{array}$ & $\begin{array}{c}\mathrm{E}_{\mathrm{rel}} \\
\left(\text { kcal mol-1) }{ }^{\mathrm{a}},\right. \\
\end{array}$ \\
\hline$A$ & -1012.103755 & 178.01581 & 0.0 \\
\hline TS1 & -1012.080944 & 176.84406 & +14.3 \\
\hline B & -1012.112208 & 178.01406 & -5.3 \\
\hline C & -534.1521621 & 177.46909 & +0.9 \\
\hline TS2 & -534.081918 & 124.64946 & +45.0 \\
\hline $\mathrm{D}$ & -534.1330484 & 128.06278 & +12.9 \\
\hline$E$ & -1012.100463 & 177.68801 & +2.1 \\
\hline TS3 & -1012.07791 & 176.74105 & +16.2 \\
\hline $\mathrm{F}$ & -1012.114764 & 178.32422 & -6.9 \\
\hline G & -534.150836 & 130.07242 & +1.7 \\
\hline TS4 & -534.0813041 & 124.88532 & +45.3 \\
\hline $\mathrm{H}$ & -534.1325096 & 127.84273 & +13.2 \\
\hline I & -1012.096112 & 177.93925 & +4.8 \\
\hline TS5 & -1012.060713 & 173.96721 & +27.0 \\
\hline J & -1012.092994 & 176.09255 & +6.7 \\
\hline K & -534.1324999 & 127.8488 & +13.2 \\
\hline L & -1012.101371 & 177.91885 & +1.5 \\
\hline TS6 & -1012.053067 & 173.63621 & +28.7 \\
\hline M & -1012.09511 & 175.66895 & +5.4 \\
\hline $\mathrm{N}$ & -534.1330465 & 128.06403 & +12.9 \\
\hline $\mathrm{O}$ & -1012.107568 & 178.4326 & -2.3 \\
\hline TS7 & -1012.058023 & 173.90797 & +28.7 \\
\hline$P$ & -1012.09213 & 175.65843 & +7.3 \\
\hline $\mathrm{Q}$ & -534.1306281 & 128.0657 & +14.4 \\
\hline $\mathrm{R}$ & -1012.09593 & 178.13605 & +4.9 \\
\hline TS8 & -1012.058689 & 173.865 & +28.3 \\
\hline $\mathrm{S}$ & -1012.088737 & 175.95845 & +9.4 \\
\hline $\mathrm{T}$ & -534.1281226 & 127.75565 & +16.0 \\
\hline U & -534.1478423 & 129.97671 & +3.6 \\
\hline TS9 & -534.0731113 & 124.95592 & +50.5 \\
\hline V & -534.1404751 & 127.10571 & +8.2 \\
\hline TS10 & -534.0641064 & 124.99521 & +56.1 \\
\hline W & -534.1249397 & 127.93632 & +18.0 \\
\hline $\mathrm{S}(\mathrm{CH} 3) 2$ & -477.9502026 & 47.51316 & 45 \\
\hline
\end{tabular}

${ }^{\mathrm{a}} \mathrm{E}_{\mathrm{rel}}=$ total energy + (ZPVE).

bEnergy relative to Structure $A$.

each transition state. The total energies, zero point vibrational energies (ZPVE), and relative energies obtained for each of the optimized transition-state structures, as well as those of the optimized precursor, intermediate, and product ion structures are given in Table 1.

Structure (TS1) in Figure 1 (A) shows the predicted low-energy transition-state structure for the loss of $\mathrm{CH}_{3} \mathrm{SCH}_{3}$ to form a protonated five-membered iminohydrofuran product ion via an $\mathrm{S}_{\mathrm{N}} 2$ neighboring group participation reaction involving the amide bond Cterminal to the methionine residue. After optimizing this structure, IRC calculations followed by geometry optimizations were performed to locate the precursor ion (A) and the intermediate product ion (B) associated with this reaction coordinate. The relative energies of the transition state and the product ion were then calculated with respect to the energy of the precursor ion. The product ion $(\mathbf{C})$ was then obtained by geometry optimization following the removal of $\mathrm{CH}_{3} \mathrm{SCH}_{3}$ from Structure (B). The relative energy of (C) was obtained by summing the energy of the product ion $(\mathbf{C})$ and the energy of the geometry optimized $\mathrm{CH}_{3} \mathrm{SCH}_{3}$. Structure (TS3) in Figure 1 (B) represents the low-energy transition-state structure for the neutral loss of $\mathrm{CH}_{3} \mathrm{SCH}_{3}$ via a neighboring group participation reaction involving the amide bond $N$-terminal to the methionine residue to form a protonated six-membered oxazine product ion. After performing IRC calculation on transition-state (TS3), the optimized precursor ion, (E) the intermediate (F) and the product ion $(\mathbf{G})$ were obtained as described above. The energies of all structures are given with respect to the energy of Structure (A) in Figure 1.

According to Figure 1, the transition-state barrier for Pathway 1, to yield the cyclic protonated five-membered iminohydrofuran ring, is predicted to be $14.3 \mathrm{kcal}$ $\mathrm{mol}^{-1}$ with respect to the energy of Structure (A), whereas the transition-state barrier to form the sixmembered oxazine ring via Pathway 2 is predicted to be $16.2 \mathrm{kcal} \mathrm{mol}^{-1}$ relative to the energy of the Structure (A). The slightly lower energy of transition-state (TS1) is likely due to better hydrogen bonding between the carbonyl oxygen and the amide nitrogen on the $N$ - and C-terminal amide bonds [1.93 $\AA$ in (TS1) versus $2.08 \AA$ in (TS3)]. The predicted difference in energies between these transition states are not considered significant enough to suggest that one of reaction Pathways, 1 or 2, would be favored over the other for the loss of $\mathrm{CH}_{3} \mathrm{SCH}_{3}$. Thus, both the five- and six-membered rings could potentially be formed. Notably, the neighboring group participation transition-state barriers predicted here for cleavage of the sulfonium ion derivatives are significantly lower than those predicted for the neighboring group participation reactions associated with the analogous loss of methane sulfenic acid $\left(\mathrm{CH}_{3} \mathrm{SOH}\right)$ from protonated methionine sulfoxide containing peptide ions (previously predicted to be $22.6 \mathrm{kcal} \mathrm{mol}^{-1}$ and $22.4 \mathrm{kcal} \mathrm{mol}^{-1}$, respectively [20], indicative of the improved leaving group ability of the sulfonium ion [20].

Figure 2 (A) shows the predicted low-energy transition-state Structure (TS5) found for the E2 elimination reaction involving intramolecular proton transfer of one of the two hydrogens from the $\beta$ methyl group of the methionine side chain to the $C$-terminal carbonyl group to subsequently yield a vinyl glycine product ion. IRC calculations were again performed to obtain the appropriate precursor and intermediate product ions (I) and (J), respectively. The structure of product ion (K) was obtained by optimization of intermediate Structure (J) after removal of $\mathrm{CH}_{3} \mathrm{SCH}_{3}$, as described above. The energies of these structures are given with respect to the energy of Structure (A) in Figure 1. Figure 2 (B) shows the predicted low-energy transition-state Structure (TS6) associated with the E2 elimination reaction involving intramolecular proton transfer of one of the two hydrogens from the $\beta$ methyl group of the methionine 


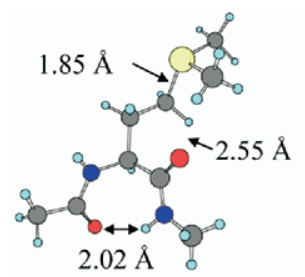

(A)

$0.0 \mathrm{kcal} \mathrm{mol}^{-1}$

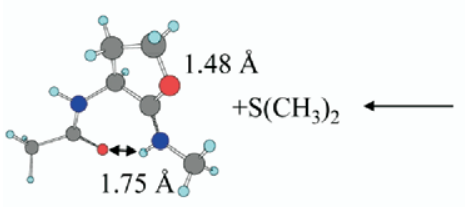

(C)

$0.9 \mathrm{kcal} \mathrm{mol}^{-1}$

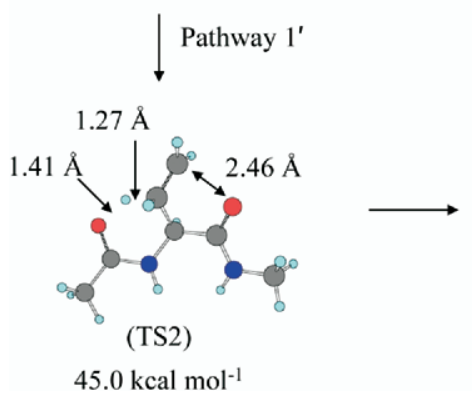

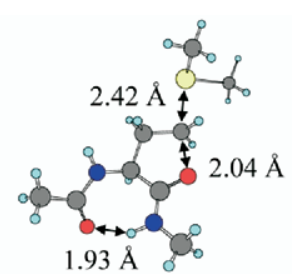

(TS1)

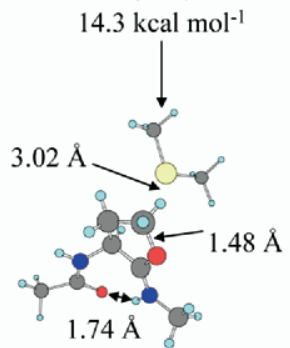

(B)

$-5.3 \mathrm{kcal} \mathrm{mol}^{-1}$

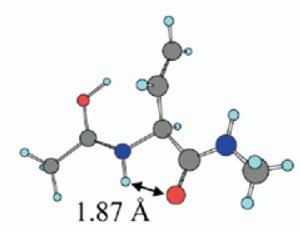

(D)

$12.9 \mathrm{kcal} \mathrm{mol}^{-1}$

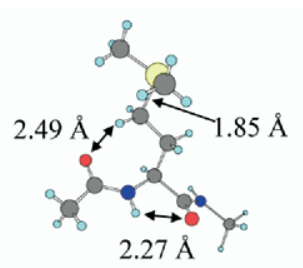

Pathway 2

(E)

$2.1 \mathrm{kcal} \mathrm{mol}^{-1}$

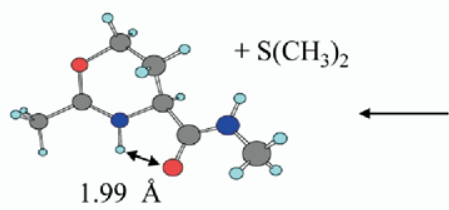

(G)

$1.7 \mathrm{kcal} \mathrm{mol}^{-1}$

$\downarrow$ Pathway 2'

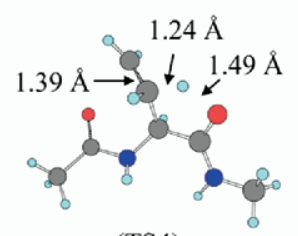

(TS4)

$45.3 \mathrm{kcal} \mathrm{mol}^{-1}$

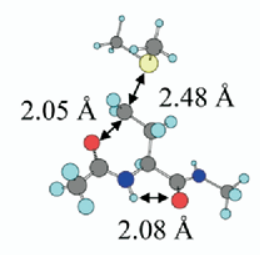

(TS3)

$16.2 \mathrm{kcal} \mathrm{mol}^{-1}$

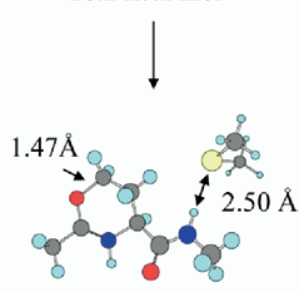

(F)

$-6.9 \mathrm{kcal} \mathrm{mol}^{-1}$

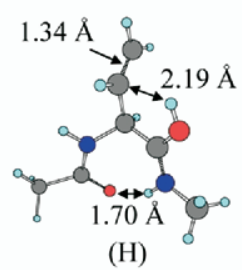

$13.2 \mathrm{kcal} \mathrm{mol}^{-1}$

Figure 1. Optimized precursor, transition-state, and product ion structures (at the B3LYP/ 6-31 + G $(\mathrm{d}, \mathrm{p})+$ ZPVE level of theory) for the loss of $\mathrm{CH}_{3} \mathrm{SCH}_{3}$ from the simple model peptide N-acetyl methionine-N-methyl amide, due to a neighboring group participation reaction involving (A) the C-terminal carbonyl group to form a five-membered iminohydrofuran product ion (Pathway 1) or (B) the $\mathrm{N}$-terminal carbonyl group to form a six-membered oxazine product ion (Pathway 2). The transition-state and product ion structures for ring opening of the initial product ion formed from Pathways 1 and 2, involving intramolecular proton transfer $\left(\beta_{1}-\mathrm{H}\right)$ to the $N$-terminal carbonyl group (Pathway $1^{\prime}$ ) or the $C$-terminal carbonyl group (Pathway $2^{\prime}$ ) to yield protonated vinyl glycine product ions, are also shown. The energies of all molecules are given relative to Structure (A) $\left(0.0 \mathrm{kcal} \mathrm{mol}^{-1}\right)$.

side chain to the $N$-terminal carbonyl group. The energies of this transition state relative to Structure (A) in Figure 1 was predicted to be $28.7 \mathrm{kcal} \mathrm{mol}^{-1}$. As there are two hydrogens on the $\beta$ methyl group in the methionine side chain, transition-state calculations predicting the barriers to the E2 elimination reactions involving the alternate hydrogens to those shown in Figure 2 were also determined. The structures associated with these transition states [Structure (TS7) in Pathway 3-2 and structure (TS8) in Pathway 4-2] are shown in Supplementary Material Figure 1S (which can be found in the online version of this article). The relative energies of these transition states were predicted to be 28.7 and $28.3 \mathrm{kcal} \mathrm{mol}^{-1}$, respectively. Thus, the four E2 elimination reaction pathways all have comparable activation barriers.

Pathways 1 and 2 illustrated in Figure 1 can be compared with Pathways 3 and 4 in Figure 2 and Pathways 3-2 and 4-2 in Supplementary Figure 1S to predict the favorable mechanistic pathway for the loss of $\mathrm{CH}_{3} \mathrm{SCH}_{3}$. The transition states associated with the neighboring group participation processes (TS1) and (TS3) both have energies $\sim 10 \mathrm{kcal} \mathrm{mol}^{-1}$ lower than those for the E2 elimination reactions (TS5), (TS6), (TS7), and (TS8). Thus, given that the significant difference in transition-state barriers between the neighboring group and E2 elimination reaction pathways suggest that Pathways 1 and 2 are likely to be more favorable, it is expected that the loss of $\mathrm{CH}_{3} \mathrm{SR}$ from the side chain of the methionine fixed charge sulfonium ion peptides will result in the formation of the five-membered iminohydrofuran and/or six-membered oxazine product ions.

\section{Examination of the Potential for Ring Opening of the Five and Six-Membered Cyclic Product Ions via Intramolecular Proton Transfer Reactions}

Having established that the initial loss of $\mathrm{CH}_{3} \mathrm{SR}$ from the side chain fixed charge sulfonium ion containing peptides following MS/MS is likely to occur via neigh- 


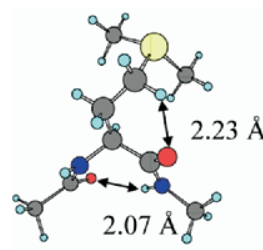

(I)

$4.8 \mathrm{kcal} \mathrm{mol}^{-1}$
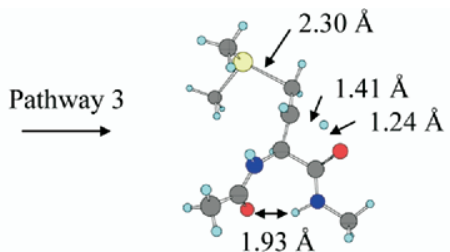

(TS5)

$27.0 \mathrm{kcal} \mathrm{mol}^{-1}$

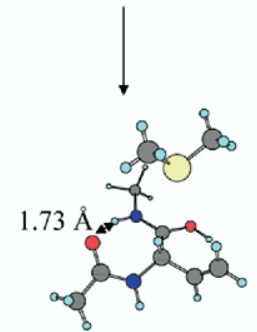

(J)

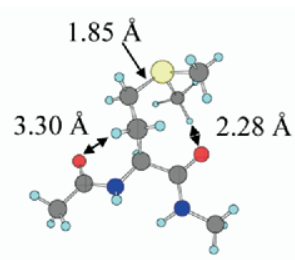

(L)

$1.5 \mathrm{kcal} \mathrm{mol}^{-1}$

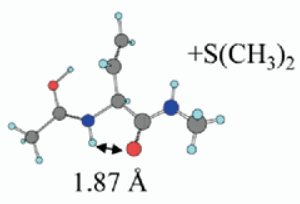

(N)

$12.9 \mathrm{kcal} \mathrm{mol}^{-1}$

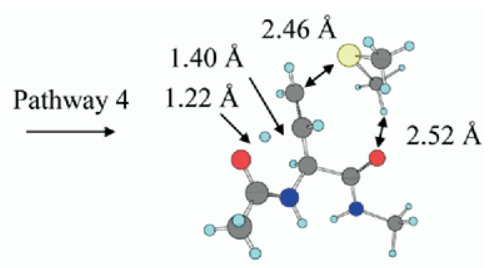

(TS6)

$28.7 \mathrm{kcal} \mathrm{mol}^{-1}$

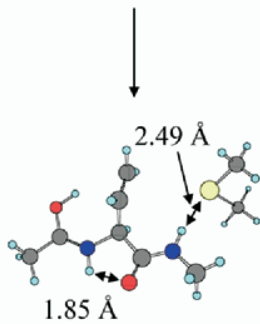

(M)

$5.4 \mathrm{kcal} \mathrm{mol}^{-1}$

Figure 2. Optimized precursor, transition-state, and product ion structures (at the B3LYP/ 6-31 + G $(\mathrm{d}, \mathrm{p})+\mathrm{ZPVE}$ level of theory) for the loss of $\mathrm{CH}_{3} \mathrm{SCH}_{3}$ from the simple model peptide $\mathrm{N}$-acetyl methionine-N-methyl amide due to intramolecular proton $\left(\beta_{1}-\mathrm{H}\right)$ transfer to $(\mathbf{A})$ the $C$-terminal carbonyl group (Pathway 3) or (B) the $N$-terminal carbonyl group (Pathway 4 ) to yield protonated vinyl glycine. The energies of all molecules are given relative to Structure (A) in Figure 1.

boring group participation mechanisms involving Pathways 1 or 2 in Scheme 2, it was then considered whether the resultant cyclic product ions could undergo ring opening to yield the acyclic vinyl glycine containing product, via intramolecular proton transfer reactions according to Pathways $1^{\prime}$ and 2' of Scheme 2, before their further dissociation by $\mathrm{MS}^{3}$. Structure (TS2) in Figure 1 (A) shows the predicted low-energy transition state for the ring opening reaction of the five-membered iminohydrofuran product ion via Pathway $1^{\prime}$ of Scheme 2. The activation barrier for Pathway $1^{\prime}$ was predicted to be $45.0 \mathrm{kcal} \mathrm{mol}^{-1}$ with respect to the energy of

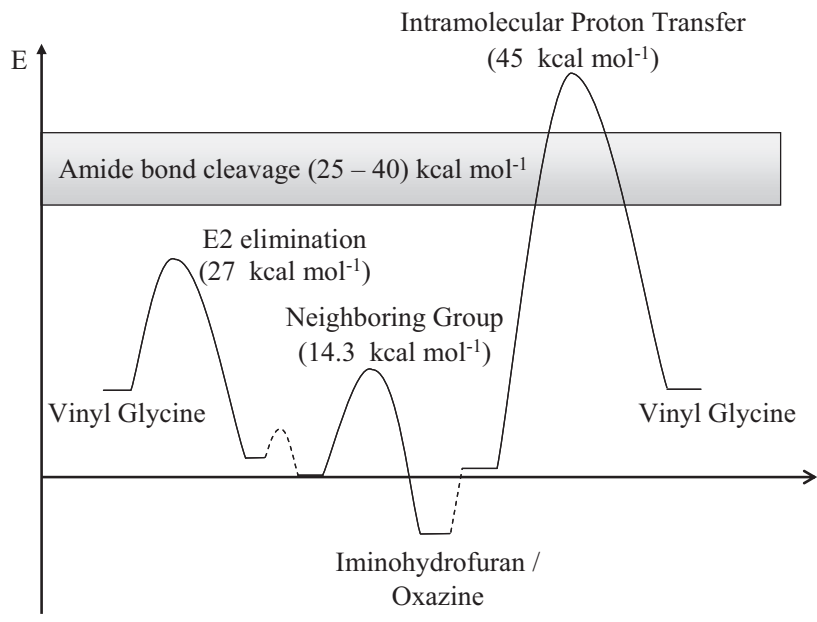

Figure 3. Summary of the predicted low-energy transition-state barriers (at the B3LYP/6-31 + G (d,p) + ZPVE level of theory) for the dissociation of methionine side chain fixed charge containing sulfonium ion peptides. The energies of all molecules are given relative to Structure (A) in Figure 1.
Structure (A). The structure of transition-state (TS2) associated with Pathway $1^{\prime}$ is similar to the structure of transition-state (TS6) associated with Pathway 4, and result in the formation of identical product ions [compare Structure (D) in Figure 1 and Structure $(\mathbf{N})$ in Figure 2]. However, transition-state (TS2) is predicted to have a significantly higher energy (45.0 $\left.\mathrm{kcal} \mathrm{mol}^{-1}\right)$ compared with transition-state (TS6) (28.7 $\mathrm{kcal} \mathrm{mol}^{-1}$ ). Justification for this difference may be obtained by consideration of the bonds being cleaved in each case, i.e., transition-state (TS2) involves cleavage of a strong carbon oxygen bond, whereas transition-state (TS6) involves cleavage of a weak carbon sulfur bond.

The predicted transition-state barrier for Pathway $2^{\prime}$ of Scheme 2 [transition-state (TS4) in Figure 1], involving ring opening of the six-membered oxazine was predicted to be $45.3 \mathrm{kcal} \mathrm{mol}^{-1}$ with respect to the energy of Structure (A), which is comparable to that predicted for ring opening of the five-membered ring in Pathway $1^{\prime}$. Similar to that discussed above, the structure of transition-state (TS4) is similar to the structure of transition-state (TS5) associated with Pathway 3, and again results in the formation of identical product ions [compare Structure $(\mathbf{H})$ in Figure 1 and Structure $(\mathbf{K})$ in Figure 2]. However, the relative energy of the ring opening transition-state (TS4) was predicted to be significantly higher than that for the E2 reaction transitionstate (TS5).

The transition-state barriers for ring opening of the five-membered iminohydrofuran product ion via intramolecular proton transfer Pathways 1'-2 and 2'-2 of Scheme 2, involving the alternate hydrogens to those shown in Figure 1 were also determined [Structures 


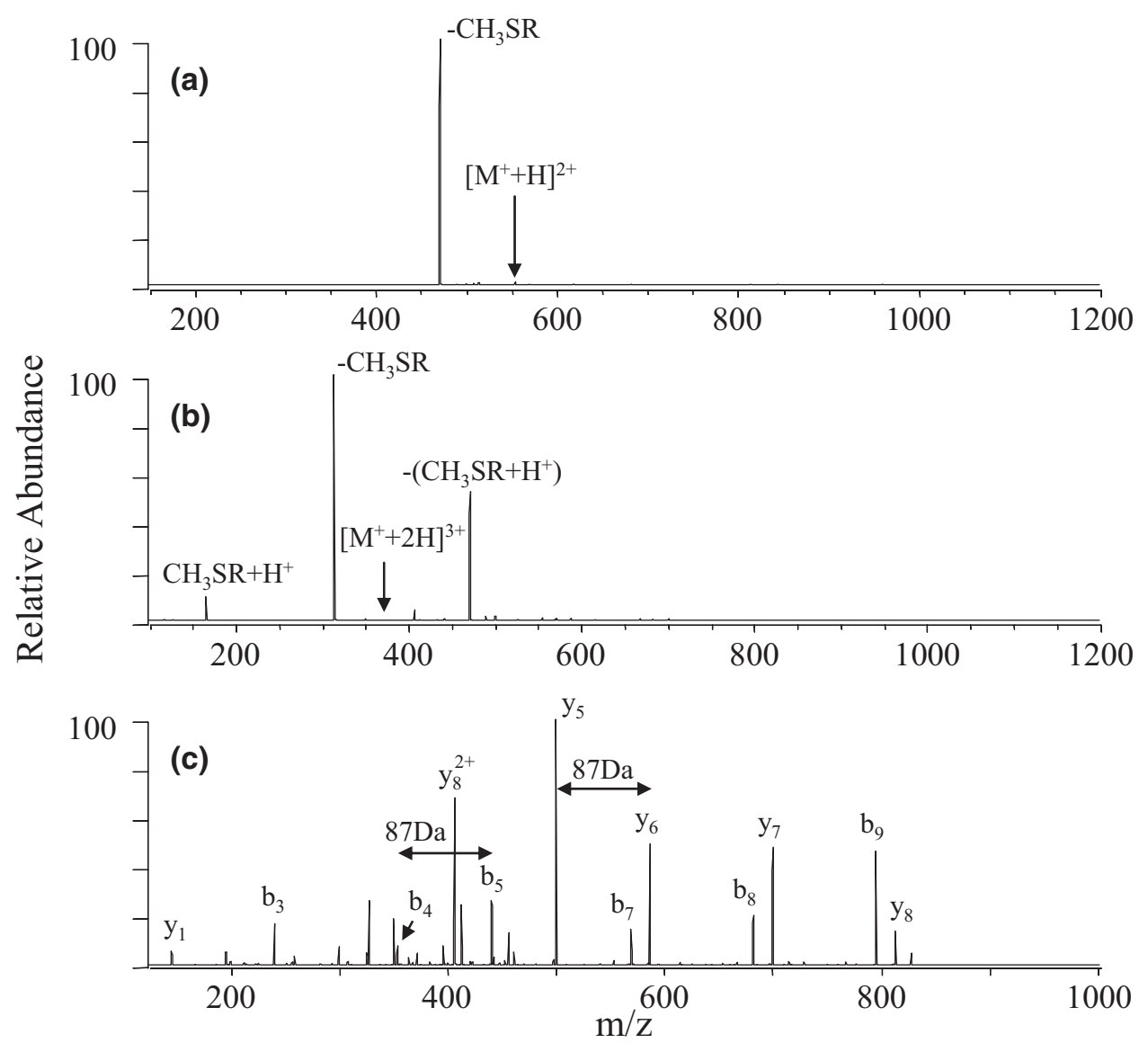

Figure 4. Linear ion trap CID MS ${ }^{\mathrm{n}}$ analysis of a methionine side chain phenacyl sulfonium ion fixed charge derivative of GAIL( $\mathrm{d}_{4}$-M)GAILK. (a) CID MS/MS product ion spectrum of the $\left[\mathrm{M}^{+}+\mathrm{H}^{+}\right]^{2+}$ ion. (b) CID MS/MS product ion spectrum of the $\left[\mathrm{M}^{+}+2 \mathrm{H}^{+}\right]^{3+}$ ion. (c) CID MS $\mathrm{MS}^{3}$ product ion spectrum of $\left[\mathrm{M}^{+}+\mathrm{H}^{+}-\mathrm{CH}_{3} \mathrm{SR}\right]^{2+}$ ion from Figure 4(a).

(TS9) and (TS10) in Supplementary Figure 2S).] The predicted barriers relative to Structure (A) for these pathways were found to be 50.5 and $56.1 \mathrm{kcal} \mathrm{mol}^{-1}$, respectively. Thus, each of the transition-state barriers predicted for Pathways $1^{\prime}, 1^{\prime}-2,2^{\prime}$, and $2^{\prime}-2$ are all significantly higher in energy than those associated with Pathways 1, 2, 3, and 4.

The transition-state barriers for amide bond cleavage reactions have been determined by numerous experimental studies and theoretical calculations to range from $\sim 25$ to $40 \mathrm{kcal} \mathrm{mol}^{-1}$, depending on proton mobility, amino acid composition, and the specific amide bond cleavage reaction under examination [24, 35-40]. Thus, the predicted low-energy transition-states (TS1) and (TS3) for the neutral loss of $\mathrm{CH}_{3} \mathrm{SR}$ via the neighboring group participation reactions discussed above are around $15 \mathrm{kcal} \mathrm{mol}^{-1}$ lower than these predicted amide bond fragmentation barriers (Figure 3). Therefore, it is expected that fragmentation of the methionine fixed charge sulfonium ion containing peptide precursors under the "slow heating" collision induced dissociation methods commonly employed for tandem mass spectrometry [41] would preferentially result in formation of the five-membered iminohydro- furan and six-membered oxazine product ions. Furthermore, given that the barriers to amide bond cleavage are expected to be much lower than the barriers predicted for the ring opening reactions of these initial cyclic product ions, it is expected that these ring opening reactions are unlikely to occur. Thus, further dissociation of the initial product ions would involve fragmentation of a mixture of both five- and six-membered ring containing ions. A summary of the predicted activation barriers associated with the various mechanistic pathways for dissociation of methionine side chain fixed charge containing sulfonium ion peptides discussed above is given in Figure 3.

\section{Regioselective Deuterium Labeling Experiments to Determine Mechanisms for the Side-Chain Fragmentation Reactions of Methionine Fixed Charge Containing Peptide Ions}

It can be seen from Scheme 2 that loss of the methionine fixed charge containing side chain via either an E2 elimination reaction would involve transfer of one of the $\beta$-methyl hydrogens in the methionine side chain, result- 


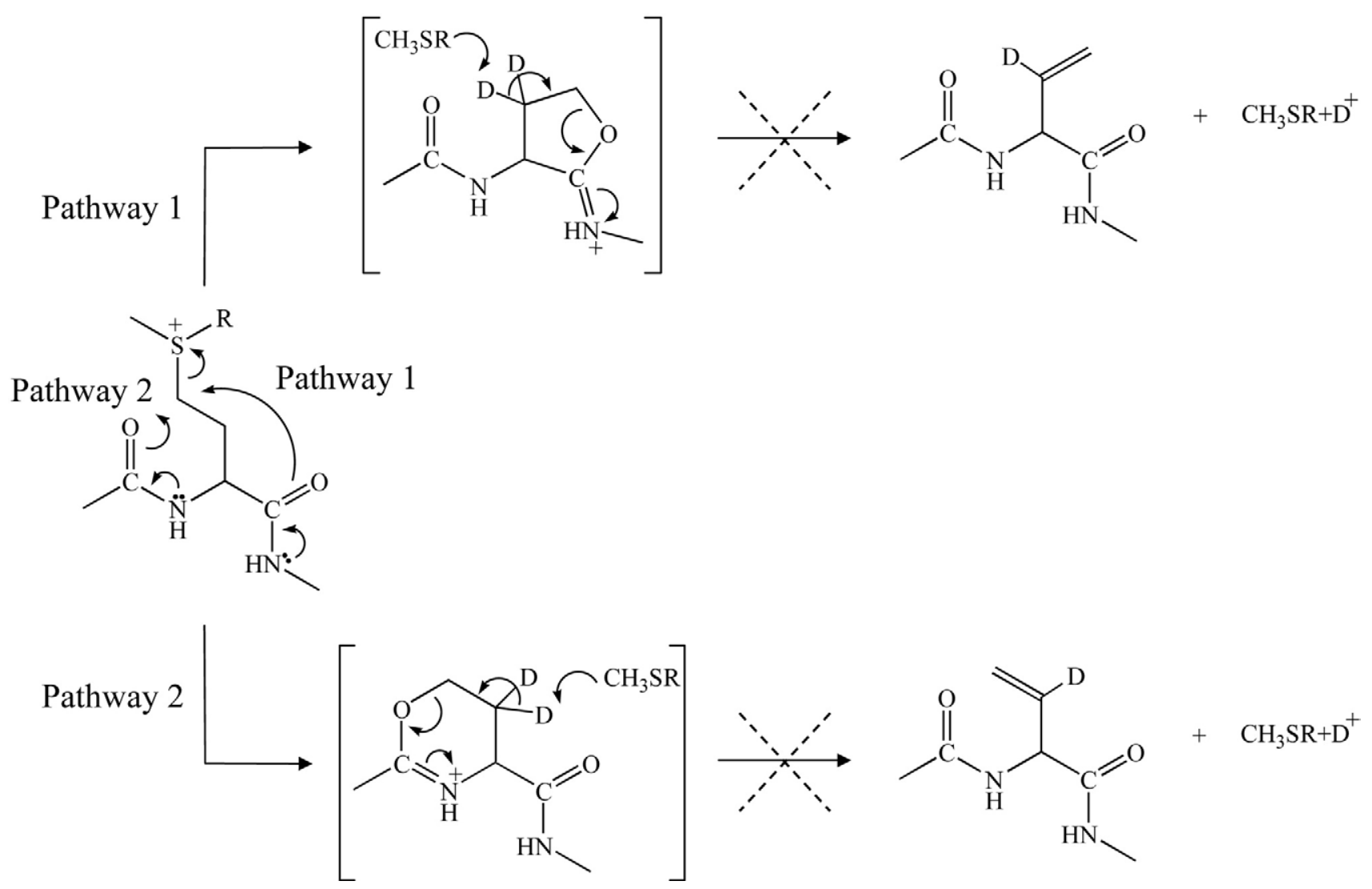

Scheme 3. Potential intermolecular deuterium transfer reactions for the charged loss of $\mathrm{CH}_{3} \mathrm{SR}+\mathrm{D}^{+}$ from methionine side chain fixed charge containing peptide ions.

ing in "mobilization" of this hydrogen along the peptide backbone. This "mobilization" would also occur if either of the $\beta$-methyl hydrogens were involved in intramolecular proton transfer ring opening reactions of the cyclic five- or six-membered iminohydrofuran or oxazine product ions initially formed via the neighboring group participation reactions. In either case, facile migration or "scrambling" of this hydrogen (proton) along the peptide backbone would be expected before or during further dissociation of the side-chain cleavage product ion by $\mathrm{MS}^{3}$ [42]. Therefore, to obtain experimental evidence to support the results from the theoretical calculations discussed above, and to determine whether or not facile scrambling of the methionine side chain $\beta$-methyl hydrogens does occur before or during $\mathrm{MS}^{3}$ dissociation, the MS/MS and $\mathrm{MS}^{3}$ fragmentation reactions of the synthetic peptide GAIL $\left(\mathrm{d}_{4}-\mathrm{M}\right)$ GAILK, containing a methionine side chain fixed charged phenacylsulfonium ion derivative, and where the hydrogens at the $\beta$ and $\gamma$ carbon positions of the methionine side chain were regioselectively exchanged for deuterium, were examined.

Figure $4 \mathrm{a}$ and $\mathrm{b}$ show the CID MS/MS product ion spectra of the doubly $\left[\mathrm{M}^{+}+\mathrm{H}^{+}\right]^{2+}$ and triply $\left[\mathrm{M}^{+}+\right.$ $\left.2 \mathrm{H}^{+}\right]^{3+}$ charged precursor ions of GAIL $\left(\mathrm{d}_{4}-\mathrm{M}(\mathrm{R})\right) \mathrm{GAILK}$, where $\mathrm{R}=\mathrm{CH}_{2} \mathrm{COC}_{6} \mathrm{H}_{5}$. For the doubly charged precursor ion product spectrum (Figure 4a), exclusive neutral loss of the fixed charge methionine side chain $\mathrm{CH}_{3} \mathrm{SR}$ was observed. By examination of the product ion spectra obtained from the triply charged precursor (Figure $4 b$ ), it can be seen that the neutral loss of $\mathrm{CH}_{3} \mathrm{SR}$ is also accompanied by "charged" loss of the fixed charge methionine side chain, giving rise to complementary $-\left(\mathrm{CH}_{3} \mathrm{SR}+\mathrm{H}^{+}\right)$ and $\mathrm{CH}_{3} \mathrm{SR}+\mathrm{H}^{+}$product ions. The formation of these protonated "charged loss" product ions indicates that the transfer of a deuterium atom via an intermolecular deuterium transfer from the $\beta$ methyl group of the methionine side chain similar to Pathways $1^{\prime}$ or $2^{\prime}$ in Scheme 2 (see Scheme 3) does not occur. This result, therefore, provides experimental evidence to support the data from the theoretical predictions that fragmentation of the fixed charge methionine side chain results in the formation of stable cyclic product ions.

Figure $4 \mathrm{c}$ shows the $\mathrm{MS}^{3}$ product ion spectrum obtained by dissociation of the neutral loss $\left[\mathrm{M}^{+}+\mathrm{H}^{+}-\right.$ $\left.\mathrm{CH}_{3} \mathrm{SR}\right]^{2+}$ product ion of the $\left[\mathrm{M}^{+}+\mathrm{H}^{+}\right]^{2+}$ precursor of GAIL $\left(\mathrm{d}_{4}-\mathrm{M}(\mathrm{R})\right)$ GAILK from Figure $4 \mathrm{a}$, from which a clear series of $b$ - and y-type ions are observed. As discussed above, if dissociation of the fixed charge containing precursor ion occurs via an E2 elimination reaction, or if ring opening of the initial cyclic product ion occurs via intramolecular proton transfer, a deuterium atom from the $\beta$ methyl group of the methionine side chain would be mobilized in the resultant product ion to a position along the peptide backbone. As a 
result, statistical "scrambling" of this deuterium along the peptide backbone would be expected. However, it can be seen from Figure $4 \mathrm{c}$ that a mass difference of 87 $\mathrm{Da}$ is observed between the $\mathrm{y}_{5}$ and $\mathrm{y}_{6}$ product ions, as well as between the $b_{4}$ and $b_{5}$ product ions. These ions represent product ions formed by fragmentation of the amide bonds on the $\mathrm{N}$ - and $\mathrm{C}$-terminal sides of the methionine residue. This mass difference, as well as the lack of evidence for deuterium incorporation into any of the other product ions formed, indicates that all four deuterium atoms are located in the side chain of the product ion, and are, therefore, not involved in the initial fragmentation reaction. This data further indicates that the E2 elimination and ring opening reactions are not involved in fragmentation of the fixed charged methionine side chain sulfonium ion peptides, and is therefore strongly suggestive of the formation of cyclic iminohydrofuran and oxazine product ions.

\section{Multistage Tandem Mass Spectrometry}

Experiments to Examine the Structure(s) of the

Product Ions Formed by Side-Chain Fragmentation of Methionine Fixed Charge Containing Peptides

The MS/MS and MS $^{3}$ data obtained from the deuterium labeling experiments above indicate that fragmentation of methionine side chain fixed charge sulfonium ion containing peptides results in the formation of cyclic five- and/or six-membered iminohydrofuran or oxazine containing product ions via neighboring group participation reaction mechanisms. Furthermore, these product ions do not undergo ring opening via intramolecular proton transfer reactions before further dissociation.

Scheme 4 shows the proposed structures of the five- and six-membered product ion formed via the loss of $\mathrm{CH}_{3} \mathrm{SR}$ from GAILM(R)GAILK, where $\mathrm{R}=$ $\mathrm{CH}_{2} \mathrm{COC}_{6} \mathrm{H}_{5}$ (Structures 1 and 2 in Scheme 4, respectively) and the structure of a "control" peptide GAILAGAILK (Structure 3 in Scheme 4). The fragmentation of product ions containing these cyclic structures, (e.g., the $\mathrm{y}_{6}$ and $\mathrm{y}_{7}$ ions from Structure 1, and the $y_{7}$ ion from Structure 2), should differ from the fragmentation of the same product ions formed from the "control" peptide lacking these cyclic structures. Therefore, to gain further insights into the structure(s) of the initial product ions formed by side-chain fragmentation of methionine fixed charge containing peptides, the multistage $\left(\mathrm{MS}^{3}\right.$ and $\mathrm{MS}^{4}$ product ion spectra of the doubly charged neutral loss product ion from the GAILM(R)GAILK peptide, as well as the MS/MS and MS ${ }^{3}$ product ion spectra of the doubly charged "control" peptide GAILAGAILK peptide have been obtained.

Figures 5a shows the $\mathrm{MS}^{3}$ product ion spectra obtained from the neutral loss $\left[\mathrm{M}^{+}+\mathrm{H}^{+}-\mathrm{CH}_{3} \mathrm{SR}\right]^{2+}$ product ion from the doubly charged precursor of GAILM(R)GAILK (note that this spectra is the nonisotopically labeled variant of that shown in Figure 4c), while Figure $5 b$ and $c$

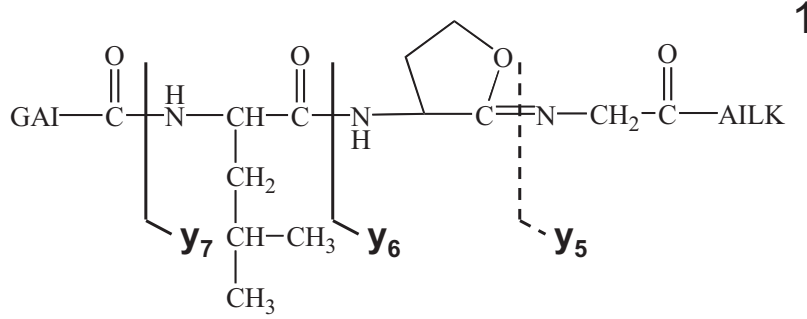

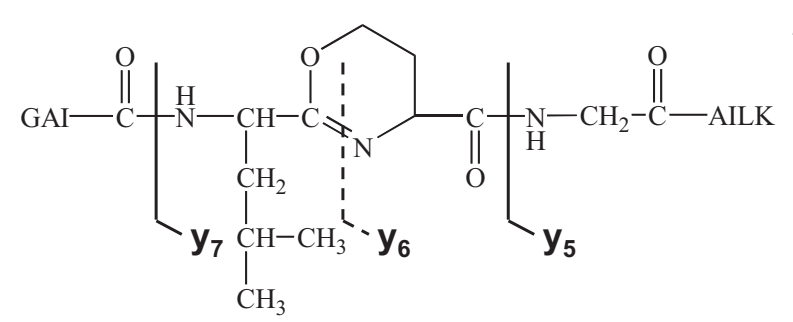

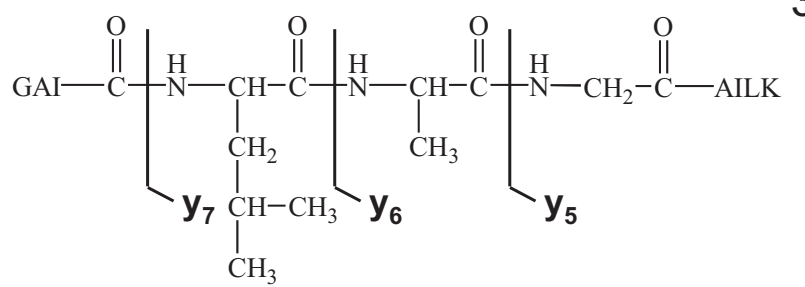

Scheme 4. Structures of (1) the five-membered iminohydrofuran product ion formed via the loss of $\mathrm{CH}_{3} \mathrm{SR}$ from GAILM(R)GAILK, (2) the six-membered oxazine product ion formed via the loss of $\mathrm{CH}_{3} \mathrm{SR}$ from GAILM(R)GAILK, and (3) GAILAGAILK. The amide bond cleavage sites for formation of the $\mathrm{y}_{5}, \mathrm{y}_{6}$, and $\mathrm{y}_{7}$ product ions in each case are indicated.

show the product ion spectra obtained by $\mathrm{MS}^{4}$ of the $\mathrm{y}_{6}$ and $y_{7}$ product ions from Figure $5 a$, respectively. Figure $5 \mathrm{~d}$ shows the MS/MS spectrum obtained from the $[\mathrm{M}+$ $\left.2 \mathrm{H}^{+}\right]^{2+}$ precursor ion of GAILAGAILK, while Figure 5e and $\mathrm{f}$ show the $\mathrm{MS}^{3}$ spectra obtained from the resultant $\mathrm{y}_{6}$ and $\mathrm{y}_{7}$ ions from Figure $5 \mathrm{~d}$. Clearly, the spectra obtained by dissociation of the $\left[\mathrm{M}^{+}+\mathrm{H}^{+}-\mathrm{CH}_{3} \mathrm{SR}\right]^{2+}$ ion from GAILM(R)GAILK and the $\left[\mathrm{M}+2 \mathrm{H}^{+}\right]^{2+}$ ion of GAILAGAILK are quite similar, with a complete series of $b$ - and $\mathrm{y}$-type ions observed in each case. Although $\mathrm{y}_{5}$ and $\mathrm{y}_{6}$ product ions corresponding to fragmentation on either side of the methionine side chain in the GAILM(R)GAILK peptide are both observed, fragmentation to yield the $\mathrm{y}_{5}$ ion is unlikely for the cyclic five-membered iminohydrofuran containing product ion (Scheme 4, Structure 1), due to the double-bond character of the amide bond. Likewise, fragmentation to yield the $\mathrm{y}_{6}$ ion is not likely to occur in the cyclic six-membered oxazine containing product ion (Scheme 4, Structure 2) due to the presence of the carbon nitrogen double bond in the oxazine ring. Thus, the fact that both ions are observed in Figure 5a suggests that both cyclic products may be formed, consistent with the similar activation energies predicted by the theoretical transitionstate calculations described earlier.

It can be seen by comparison of Figure $5 b$ with e and Figure $5 \mathrm{c}$ with $\mathrm{f}$ that the product ion spectra obtained by dissociation of the $\mathrm{y}_{6}$ and $\mathrm{y}_{7}$ ions from 
100

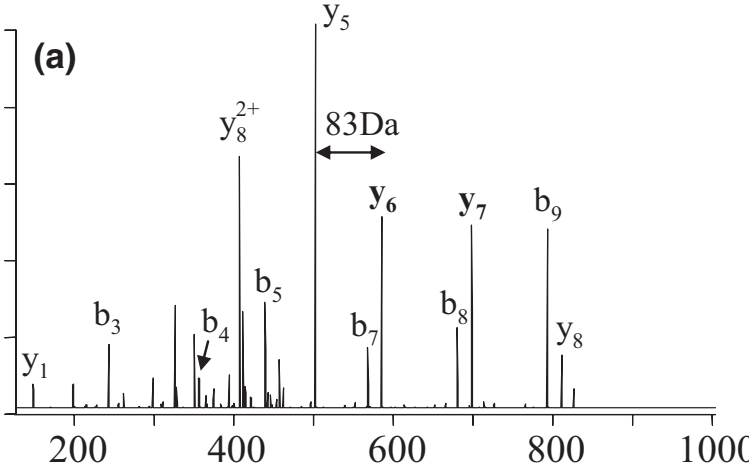

100

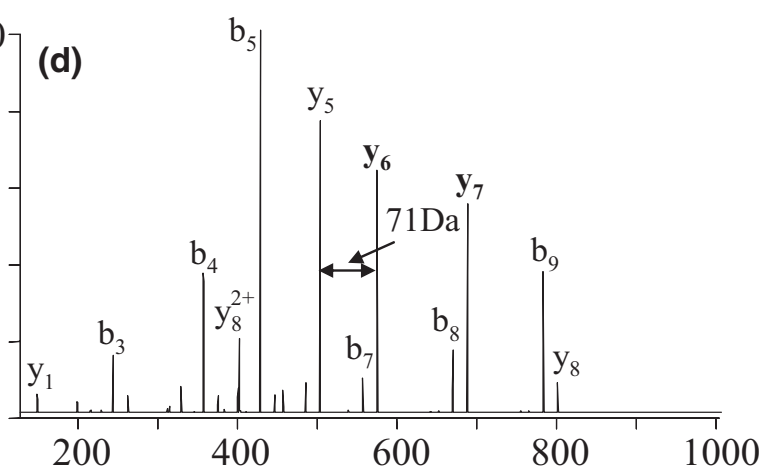

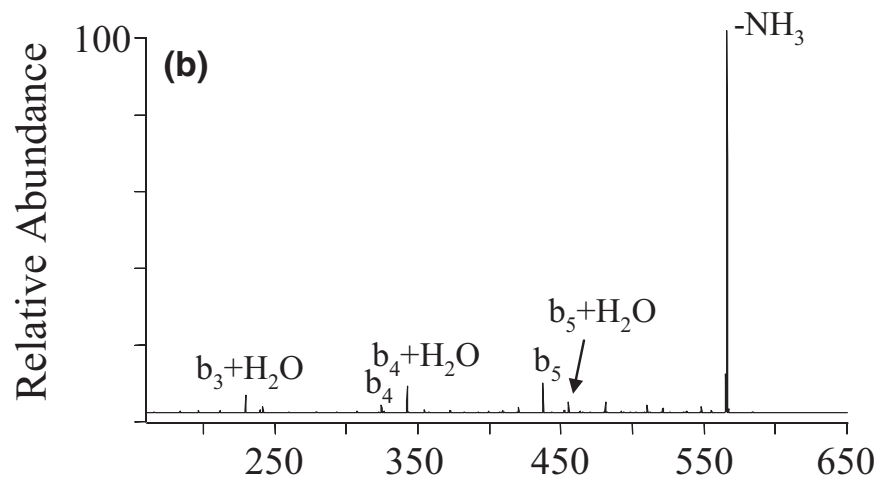

100

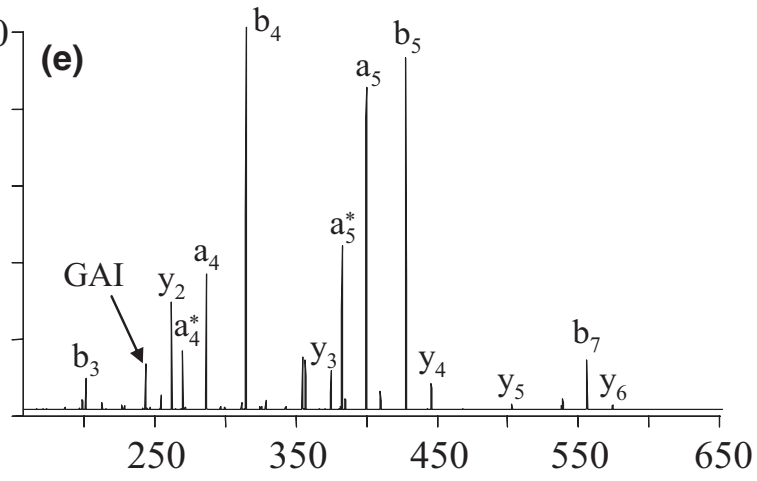

100
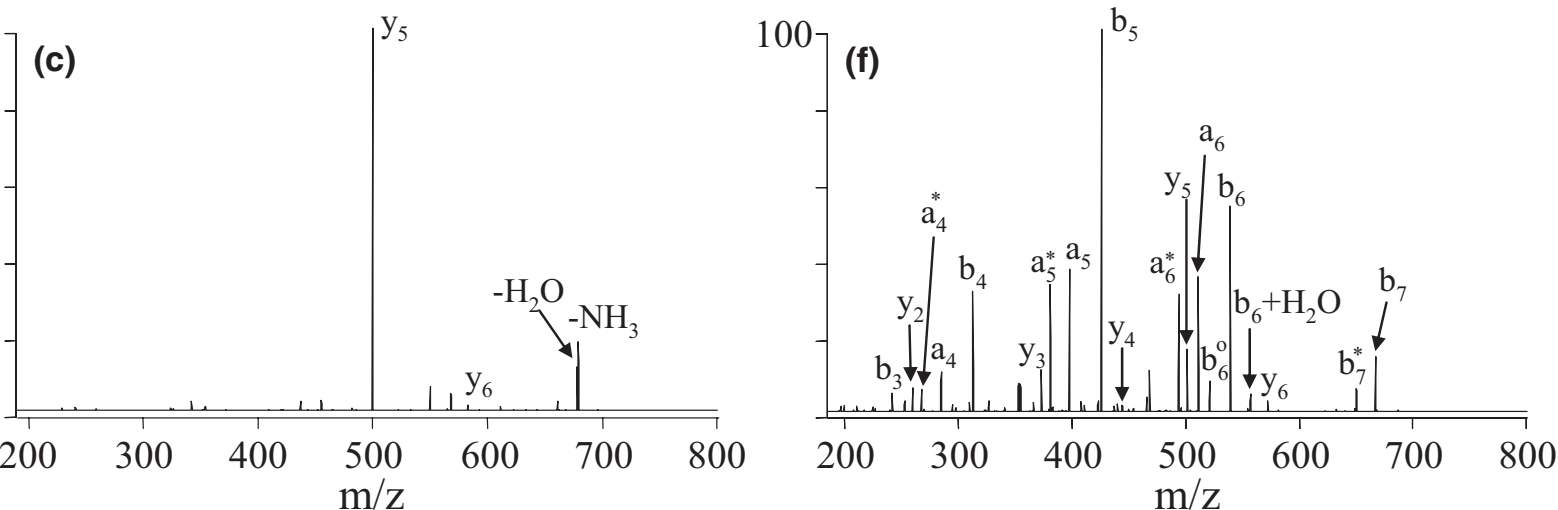

Figure 5. Multistage (MS/MS, $\mathrm{MS}^{3}$ and $\mathrm{MS}^{4}$ tandem mass spectrometry analysis of GAILM(R)GAILK (where $\mathrm{R}=\mathrm{CH}_{2} \mathrm{COC}_{6} \mathrm{H}_{5}$ ) and GAILAGAILK. (a) CID MS ${ }^{3}$ product ion spectrum of the $\left[\mathrm{M}^{+}+\mathrm{H}^{+}-\right.$ $\left.\mathrm{CH}_{3} \mathrm{SR}\right]^{2+}$ ion from GAILM(R)GAILK. (b) CID MS ${ }^{4}$ product ion spectrum of the $\mathrm{y}_{6}$ product ion from Figure 5a. (c) $\mathrm{CID} \mathrm{MS}^{4}$ product ion spectrum of the $\mathrm{y}_{7}$ product ion from Figure 5a. (d) CID MS/MS product ion spectrum of the $\left[\mathrm{M}+2 \mathrm{H}^{+}\right]^{2+}$ ion of GAILAGAILK (e) CID MS ${ }^{3}$ product ion spectrum of the $\mathrm{y}_{6}$ product ion from Figure $5 \mathrm{~d}$. (f) $\mathrm{CID} \mathrm{MS} \mathrm{S}^{3}$ product ion spectrum of the $\mathrm{y}_{7}$ product ion from Figure $5 \mathrm{~d}$.

the two peptides are very different. It is expected that these differences are due to the presence of the cyclic structures in the GAILM(R)GAILK peptide upon loss of the side chain. The series of product ions observed in Figure $5 \mathrm{e}$ and $\mathrm{f}$ by dissociation of the $\mathrm{y}_{6}$ and $\mathrm{y}_{7}$ ions from the $\left[\mathrm{M}+2 \mathrm{H}^{+}\right]^{2+}$ ion of the GAILAGAILK peptide correspond to a relatively complete series of $\mathrm{a}-, \mathrm{b}-$, and $y$-type ions. In contrast, the $\mathrm{y}_{6}$ ion from the $\left[\mathrm{M}^{+}+\mathrm{H}^{+}-\mathrm{CH}_{3} \mathrm{SR}\right]^{2+}$ ion of the GAILM(R)GAILK peptide may contain only the five-membered iminohydrofuran ring, whereas the $\mathrm{y}_{7}$ product ion may contain either the five-membered iminohydrofuran or the sixmembered oxazine rings. The dominant product ions observed by dissociation of these $\mathrm{y}_{6}$ and $\mathrm{y}_{7}$ ions (Figure $5 \mathrm{~b}$ and $\mathrm{c}$, respectively) correspond to the loss of $\mathrm{NH}_{3}$ and/or the formation of a $y_{5}$ ion. The loss of $\mathrm{NH}_{3}$ in Figure $5 b$ is consistent with fragmentation of the fivemembered iminohydrofuran ring containing $\mathrm{y}_{6}$ precursor ion, while the formation of the $\mathrm{y}_{5}$ ion in Figure $5 \mathrm{c}$ is consistent with fragmentation of the six-membered oxazine ring containing $\mathrm{y}_{7}$ product ion.

\section{Conclusions}

Taken together, the results obtained from the theoretical calculations and experimental data presented here indi- 
cate that the loss of $\mathrm{CH}_{3} \mathrm{SR}$ from methionine side chain fixed charge sulfonium ion containing peptide ions occurs via neighboring group participation $\mathrm{S}_{\mathrm{N}} 2$ elimination reactions, resulting in the formation of a mixture of both five-membered iminohydrofuran and six-membered oxazine product ions. The data obtained also indicates that these cyclic product ions do not rearrange by intermolecular proton transfer reactions before or during further dissociation. However, the resultant product ion spectra obtained by $\mathrm{MS}^{3}$ are not significantly different from the spectra obtained from "control" acyclic peptides, particularly with respect to the formation of product ions resulting from cleavage of amide bonds either side of the site of the loss of the fixed charge. This is likely due to the presence of a mixture of both cyclic structures formed from the initial neutral loss.

\section{Acknowledgments}

Support for this work was provided by a National Science Foundation CAREER Award to GER (grant no: CHE 0547940).

\section{References}

1. Mann, M.; Hendrickson, R. C.; Pandey, A. Analysis of Proteins and Proteomes by Mass Spectrometry. Annu. Rev. Biochem. 2001, 70, 437473

2. Aebersold, R.; Goodlett, D. R. Mass Spectrometry in Proteomics. Chem. Rev. 2001, 101, 269-295

3. Aebersold, R.; Mann, M. Mass Spectrometry-Based Proteomics. Nature 2003, 422, 198-207.

4. Ong, S.-E.; Mann, M. Mass Spectrometry-Based Proteomics Turns Quantitative. Nature Chem. Biol. 2005, 1, 252-262.

5. Hunt, D. F.; Yates, J. R.; Shabanowitz, J.; Winston, S.; Hauer, C. R. Protein Sequencing by Tandem Mass Spectrometry. Proc. Natl. Acad. Sci. U.S.A. 1986, 83, 6233-6237.

6. Steen, H.; Mann, M. The ABC's (and XYZ's) of Peptide Sequencing. Nat. Rev. Mol. Cell Biol. 2004, 5, 699-711.

7. Mann, M.; Jensen, O. N. Proteomics Analysis of Post-Translational Modifications. Nat. Biotechnol. 2003, 21, 255-261.

8. Thompson, A.; Schaefer, J.; Kuhn, K.; Kiene, S.; Schwarz, J.; Schmidt, G.; Johnstone, R.; Neumann, T.; Hamon, C. Tandem Mass Tags: A Novel Quantification Strategy for Comparative Analysis of Complex Protein Mixtures by MS/MS. Anal. Chem. 2003, 75, 1895-1904.

9. Ross, P. L.; Huang, Y. N.; Marchese, J. N.; Williamson, B.; Parker, K.; Hattan, S.; Khainovski, N.; Pillai, S.; Dey, S.; Daniels, S.; Purkayastha, S. Juhasz, P.; Martin, S.; Bartlet-Jones, M.; He, F.; Jacobson, A.; Pappin, D. J. Multiplexed Protein Quantitation in Saccharomyces cerevisiae Using Amine-Reactive Isobaric Tagging Reagents. Mol. Cell. Proteom. 2004, 3, 1154-1169.

10. Sadygov, R. G.; Cociorva, D.; Yates, J. R. Large-Scale Database Searching Using Tandem Mass Spectra: Looking up the Answer in the Back of the Book. Nature Methods 2004, 1, 195-202.

11. Hernandez, P; Muller, M; Appel, R. D. Automated Protein Identification by Tandem Mass Spectrometry: Issues and Strategies. Mass Spectrom. Rev. 2006, 25, 235-254.

12. Eng, J. K.; McCormack, A. L.; Yates, J. R. An Approach to Correlate Tandem Mass Spectral Data of Peptides with Amino Acid Sequences in a Protein Database. J. Am. Soc. Mass Spectrom. 1994, 5, 976-989.

13. Perkins, D. N.; Pappin, D. J. C.; Creasy, D. M.; Cottrell, J. S. ProbabilityBased Protein Identification by Searching Sequence Databases Using Mass Spectrometry Data. Electrophoresis 1999, 20, 3551-3567.

14. Yates, J. R.; Eng, J. K.; McCormack, A. L.; Schieltz, D. Method to Correlate Tandem Mass Spectra of Modified Peptides to Amino Acid Sequences in the Protein Database. Anal. Chem. 1995, 67, 1426-1436.

15. MacCoss, M. J.; Wu, C. C.; Yates, J. R. Probability-Based Validation of Protein Identifications Using a Modified SEQUEST Algorithm. Anal. Chem. 2002, 74, 5593-5599.

16. Creasy, D. M.; Cottrell, J. S. Error Tolerant Searching of Uninterpreted Tandem Mass Spectrometry Data. Proteomics 2002, 2, 1426-1434.

17. Dongre, R. A.; Jones, J. L.; Somogyi, A.; Wysocki, V. H. Influence of Peptide Composition, Gas-Phase Basicity, and Chemical Modification on Fragmentation Efficiency: Evidence for the Mobile Proton Model. J. Am. Chem. Soc. 1996, 118, 8365-8374.

18. Wysocki, V. H.; Tsaprailis, G.; Smith, L. L.; Breci, L. A. Mobile and Localized Protons: A Framework for Understanding Peptide Dissociation. J. Mass Spectrom. 2000, 35, 1399-1406.
19. Kapp, E. A.; Schultz, F.; Reid, G. E.; Eddes, J. S.; Moritz, R. L.; O'Hair, R. A. J.; Speed, T. P.; Simpson, R. J. Mining a Tandem Mass Spectrometry Database to Determine the Trends and Global Factors Influencing Peptide Fragmentation. Anal. Chem. 2003, 75, 6251-6264.

20. Reid, G. E.; Roberts, K. D.; Kapp, E. A.; Simpson, R. J. Statistical and Mechanistic Approaches to Understanding the Gas-Phase Fragmentation Behavior of Methionine Sulfoxide Containing Peptides. J. Proteome Res. 2004, 3, 751-759.

21. Jin, M.; Bateup, H.; Padovan, J. C.; Greengard, P.; Nairn, A. C.; Chait, B. T. Quantitative Analysis of Protein Phosphorylation in Mouse Brain by Hypothesis-Driven Multistage Mass Spectrometry. Anal. Chem. 2005, $77,7845-7851$.

22. Simpson, R. J.; Connelly, L. M.; Eddes, J. S.; Pereira, J. J.; Moritz, R. L.; Reid, G. E. Proteomic Analysis of the Human Colon Carcinoma Cell Line (LIM 1215): Development of a Membrane Protein Database. Electrophoresis 2000, 21, 1707-1732.

23. O'Hair, R. A. J. The Role of Nucleophile-Electrophile Interactions in the Unimolecular and Bimolecular Gas-Phase Ion Chemistry of Peptides and Related Systems. J. Mass Spectrom. 2000, 35, 1377-1381.

24. Paizs, B.; Suhai, S. Fragmentation Pathways of Protonated Peptides. Mass Spectrom. Rev. 2005, 24, 508-548.

25. Anderegg, R. J. Derivatization in Mass Spectrometry: Strategies for Controlling Fragmentation. Mass Spectrom. Rev. 1988, 7, 395-424.

26. Roth, K. D. W.; Huang, Z. H.; Sadagopan N.; Watson J. T. Charge Derivatization of Peptides for Analysis by Mass Spectrometry. Mass Spectrom. Rev. 1998, 17, 255-274.

27. Adamczyk, M.; Gebler, J. C.; Wu, J. Charge Derivatization of Peptides to Simplify their Sequencing with an Ion Trap Mass Spectrometer. Rapid Commun. Mass spectrum. 1999, 13, 1413-1422.

28. Sadagopan, N.; Watson, J. T. Mass Spectrometric Evidence for Mechanisms of Fragmentation of Charge-Derivatized Peptides. J. Am. Soc. Mass Spectrom. 2001, 12, 399-409.

29. Keough, T.; Youngquist, R. S.; Lacey, M. P. Sulfonic Acid Derivatives for Peptide Sequencing by MALDI MS. Anal. Chem. 2003, 75, 156A-165A.

30. Sidhu, K. S.: Sangvanich, P.; Brancia, F. L.; Sullivan, A. G.; Gaskell, S. J.; Wolkenhauer, O.; Oliver, S. G.; Hubbard, S. J. Bioinformatic Assessment of Mass Spectrometric Chemical Derivatization Techniques for Proteome Database Searching. Proteomics 2001, 1, 1368-1377.

31. Locke, S. J.; Leslie, A. D.; Melanson, J. E.; Pinto, D. M. Deviation from the Mobile Proton Model in Amino-Modified Peptides: Implications for Multiple Reaction Monitoring Analysis of Peptides. Rapid Commun. Mass Spectrom. 2006, 20, 1525-1530.

32. Gu, C.; Tsaprailis, G.; Breci, L.; Wysocki, V. H. Selective Gas-Phase Cleavage at the Peptide Bond C-Terminal to Aspartic Acid in FixedCharge Derivatives of Asp-Containing Peptides. Anal. Chem. 2000, 72, 5804-5813

33. Reid, G. E.; Roberts, K. D.; Simpson, R. J.; O'Hair, R. A. J. Selective Identification and Quantitative Analysis of Methionine Containing Peptides by Charge Derivatization and Tandem Mass Spectrometry. J. Am. Soc. Mass Spectrom. 2005, 16, 1131-1150.

34. Frisch, M. J.; Trucks, G. W.; Schlegel, H. B.; Scuseria, G. E.; Robb, M. A.; Cheeseman, J. R.; Zakrzewski, V. G.; Montgomery, J. A., Jr.; Stratman, R. E.; Burant, J. C.; Dapprich, S.; Millam, J. M.; Daniels, A. D.; Kudin, K. N.; Strain, M. C.; Farkas, O.; Tomasi, J.; Barone, V.; Cossi, M.; Cammi, R.; Mennucci, B.; Pomelli, C.; Adamo, C.; Clifford, S.; Ochterski, J.; Petersson, G. A.; Ayala, P. Y.; Cui, Q.; Morokuma, K.; Malick, D. K.; Rabuck, A. D.; Raghavachari, K.; Foresman, J. B.; Cioslowski, J.; Ortiz, J. V.; Baboul, A. G.; Stefanov, B. B.; Liu, G.; Liashenko, A.; Piskorz, P.; Komaromi, I.; Gomperts, R.; Martin, R. L.; Fox, D. J.; Keith, T.; Al-Laham, M. A.; Peng, C. Y.; Nanayakkara, A.; Gonzalez, C.; Challacombe, M.; Gill, P. M. W.; Johnson, B.; Chen, W.; Wong, M. W.; Andres, J. L.; Head-Gordon, M.; Replogle, E. S.; Pople, J. A. Gaussian 98, Revision A. 7, 1998; Gaussian, Inc.: Pittsburgh, PA.

35. Klassen, J. S.; Kebarle, P. Collision-Induced Dissociation Threshold Energies of Protonated Glycine, Glycinamide, and Some Related Small Peptides and Peptide Amino Amides. J. Am. Chem. Soc. 1997, 119, 6552-6563.

36. Rodriquez, C. F.; Cunje, A.; Shoeib, T.; Chu, I. K.; Hopkinson, A. C.; Siu, K. W. M. Proton Migration and Tautomerism in Protonated Triglycine. J. Am. Chem. Soc. 2001, 123, 3006-3012.

37. El Aribi, H.; Rodriquez, C. F.; Almeida, D.R.P.; Ling, Y.; Mak, W.W.-N. Hopkinson, A. C.; Siu, K. W. M. Elucidation of Fragmentation Mechanisms of Protonated Peptide Ions and Their Products: A Case Study on Glycylglycylglycine Using Density Functional Theory and Threshold Collision-Induced Dissociation. I. Am. Chem. Soc. 2003, 125, 9229-9236.

38. El Aribi, H.; Orlova, G.; Rodriquez, C. F.; Almeida, D.R.P.; Hopkinson, A. C.; Siu, K. W. M. Fragmentation Mechanisms of Product Ions from Protonated Tripeptides. J. Phys. Chem. B 2004, 108, 18743-18749.

39. Laskin, J.; Bailey, T. H.; Futrell, J. H. Fragmentation Energetics for Angiotensin II and Its Analogs from Time- and Energy-Resolved Surface-Induced Dissociation Studies. Int. J. Mass Spectrom. 2004, 234, 89-99.

40. Paizs, B.; Suhai, S. Towards Understanding the Tandem Mass Spectra of Protonated Oligopeptides. 1: Mechanism of Amide Bond Cleavage. J. Am. Soc. Mass Spectrom. 2004, 15, 103-113.

41. Mcluckey, S. A.; Goeringer, D. E. Slow Heating Methods in Tandem Mass Spectrometry. J. Mass Spectrom. 1997, 32, 461-474.

42. Johnson, R. S.; Krylov, D.; Walsh, K. A. Proton Mobility Within Electrosprayed Peptide Ions. J. Mass Spectrom. 1995, 30, 386-387. 